\title{
Effect of Bank Specific Factors on Profitability of Commercial Banks in Ethiopia
}

\author{
Haimiro Lingerih Zerihun \\ Department of Accounting and Finance, College of Business and Economics, Hawassa University, Hawassa, Ethiopia
}

\section{Email address:}

haimiro3@gmail.com

\section{To cite this article:}

Haimiro Lingerih Zerihun. Effect of Bank Specific Factors on Profitability of Commercial Banks in Ethiopia. Journal of Finance and Accounting. Vol. 9, No. 2, 2021, pp. 23-27. doi: 10.11648/j.jfa.20210902.11

Received: October 10, 2020; Accepted: October 28, 2020; Published: April 16, 2021

\begin{abstract}
Financial institutions specifically commercial banks play a significant and energetic role for developing an economy of a country. When the banking sector in a country is functioning in an efficient, effective, and disciplined way it leads to bring a rapid growth in the various sectors in the country. Many factors may impact on profitability of commercial banks. Basically, it can be categorized as bank internal factors and bank external factors. This paper tried to investigate the effect of bank specific factors on profitability of selected commercial banks in Ethiopia. The researcher identified return on asset as a dependent variable whereas bank size, capital ratio and management efficiency as an independent variables. For the achievement of the objectives the researcher collected secondary data in the form of annual audited financial statements from eight selected sampled commercial banks to investigate the effect of selected bank specific factors on profitability for six years from 2013 to 2018. In order to select sampled banks from all the total of 17 commercial banks operating, purposive sampling method was employed. This study adopted an explanatory approach by using panel data research design to fulfill the objectives. The collected data have been analyzed using random effect model of panel data analysis. The results of the study shows that capital ratio and management efficiency are positively related with profitability but bank size negatively related with profitability. Bank size significantly negatively affects profitability, capital ratio insignificantly positively affects profitability and management efficiency significantly positively affects profitability of banks. It is concluded that management efficiency is the major factor of profitability from the variables included in the model.
\end{abstract}

Keywords: Specific Factors, Bank Profitability, Commercial Banks, Panel Data

\section{Introduction}

Financial institutions are one of the most important components of any country's financial system. They play a vital role in determining the effectiveness and efficiency of the financial system, and comes in the importance of financial institutions in that they provide the economy services for richer than them. They represent the vital infrastructure through which money flows from savings to investors in various economic fields.

Financial institutions specifically commercial banks play a significant and energetic role for developing an economy of a country. When the banking sector in a country is functioning in an efficient, effective, and disciplined way it leads to bring a rapid growth in the various sectors in the country. Many factors may impact on profitability of commercial banks. Basically, it can be categorized as bank internal factors and bank external factors. Bank internal or specific factors are bank size, capital adequacy, liquidity risk, operating expense ratio, asset quality, net interest margin, management efficiency and etc (Rudhani et al., 2016 and Abdu et al., 2018). These factors can be controlled by management of the bank. Whereas the external factors like interest rate, inflation and gross domestic products are beyond the control of management of the bank.

Different researches in different countries are conducted to investigate the effect of bank specific factors on the profitability of banks. But there is no uniformity on the result of the effect of bank specific factors on profitability of banks. Gicharu, et al. (2016) conducted a study in Kenya to investigate the effect of bank specific factors on profitability of commercial banks and found that capital adequacy, asset 
quality, management efficiency and earning ability have positive effect on profitability where as bank size and deposit have a negative effect on profitability [1]. Mahmud, et al. (2016) revealed in their study capital adequacy ratio, bank size, operating expense ratio and gearing ratio have a positive impact on profitability but liquidity and non-performing loans are not important determinants of profitability of commercial banks in Bangladish [2] where as a study by Hirindu and Kushani (2017) found that size, capital ratio, deposit ratio have positive significant factors of profitability of domestic commercial banks in Sri Lankan [11]. Kawshala and Panditharathna (2017) found that bank size, capital ratio and deposit ratio have positive significant effect on profitability of banks in Pakistan [3]. Serwadda (2018) revealed that overhead cost and liquidity risk have negative effect on profitability whereas net interest margin and capital adequacy ratio have no impact on profitability of banks [4]. Haliti, et al. (2016) found that in their study profit will increase by increasing the level of bank loaning and other investments except for managing risk and liquidity properly [10]. A study by Sabri (2016) on the internal determinants of bank profitability in Turkey found that the ratio of net fees and commission to total expense and interest from loan to interest on deposit have a positive effect on profitability, the ratio of other operating expense to total operating income have positive effect on profitability and the ratio of equity to long term subordinated loans to total asset have positive but insignificant effect on profitability [12] whereas Ongore and Kusa (2013) found that solvency ratio and turnover ratio have positive significant effect on profitability [13]. Bhatia, et al. (2012) conducted a study on the determinants of profitability in private banks in India and found that spread ratio, provisions and contingencies, non interest income, operating expense ratio, profit per employees, investment ratio and non performing assets are significant variables affecting profitability [14]. Sufian and Habibullah (2009) and Macit (2011) also conduct a study on bank specific and macroeconomic determinants of profitability of banks in China and Turkey respectively [15] and [16] and Macit (2011) found that ratio of non-performing loan to total asset have a negative and significant effect on profitability but real assets have a positive effect on profitability [16]. There is no uniformity on the result of the study conducted in different countries. Therefore, this study is intended to examine the effect of bank specific factors on profitability of commercial banks in Ethiopia.

The study has the following specific objectives:

1) to examine the effect of bank size on profitability

2) to investigate the impact of capital ratio on profitability

3) to depict the effect of management efficiency on profitability

\section{Empirical Literatures}

Bank size (BS)

Bank size is measured in terms of total asset of banks. A study done by Kawshala and Panditharathna (2017) and
Mohammed (2018) revealed that bank size has a significant positive impact on profitability [3] and [5]. But a study made by Rahaman and Akhter (2015) indicated that bank size has a significant negative effect on profitability [6] and Suganya and Kengatharan (2018) identified that bank size do not have any significant impact on profitability [7]. Serwadda (2018) identified as a factor having biggest impact on profit [4] and Mahmud, et al. (2016) also identified as an important variable affecting profit but both did not indicate the magnitude and direction of the effect of bank size on profit [2]. Bank size can be calculated using:

$$
\text { Bank size }=\log (\text { total asset of banks })
$$

H1: Bank size has a significant impact on profitability of commercial banks

\section{Capital ratio $(C R)$}

Capital ratio is calculated as a ratio of total equity to total asset. A study made by Nguyen, et al. (2018) in Vietnam revealed that capital size has a significant positive impact on profitability [8] and Kawshala and Panditharathna (2017) identified capital ratio as a significant positive factor of profitability [3]. Maqbool and Kouser (2015) also identified capital ratio having significant effect on profitability but did not indicate the magnitude and direction of its effect [9]. Capital ratio is calculated as:

$$
\text { Capital ratio }=\text { Total equity } / \text { Total asset }
$$

$\mathrm{H} 2$ : Capital ratio has a significant impact on profitability of commercial banks.

\section{Management efficiency (ME)}

The average profit per employee is taken as indicator of the measure of management efficiency. Mohammed (2018) identified management efficiency as a significant positive factor of profitability [5] and Gicharu, et al. (2016) identified management efficiency as a positive factor of profitability [1] But a study made by Suganya and Kengatharan (2018) indicated that management efficiency do not have any significant impact on profitability [7]. Management efficiency calculated as:

\section{Management efficiency $=$ Profit $/$ Number of employees}

H3: Management efficiency has a significant impact on profitability of commercial banks

\section{Materials and Methods}

\section{Research Design}

In order to carry out this study, quantitative data on bank specific factors and profitability measures have been collected from the annual audited financial statements of selected commercial banks operating in Ethiopia. The study has been conducted using panel data, secondary data collected for the period of six years from 2013 to 2018 .

\section{Target population}

The target populations of the study are all the 18 commercial banks operating in Ethiopian financial system. 


\section{Sampling method and sample size}

The researcher has used purposive sampling method to select the sample banks from the target population. The researcher purposively selected eight banks based on their operating life and having annual audited financial statements for the last six consecutive years from 2013 to 2018 .

\section{Method of data analysis}

After the data have been collected from the sampled banks descriptive statistics and multiple regression model was adopted. Stata version 13 software was used to process and analyze the data.

Summary of variables and their expected sign

\begin{tabular}{lllll}
\hline No & Independent Variable & Measurement of variable & Conception & Expected sign \\
\hline 1 & Bank size & Logarithm of total asset & BS & CR \\
2 & Capital Ratio & Equity / Total assets & ME \\
3 & Management efficiency & Profit / no. of employees & + \\
\hline
\end{tabular}

Regression model specification

In order to evaluate the effect of bank specific factors on profitability of commercial banks the following regression model with one dependent variable and three independent variables have been developed. As presented below, multiple regression model was adopted to show the effect of bank specific factors on profitability of commercial banks:

$$
\begin{gathered}
\text { Yit }=\beta 0 \text { it }+\beta 1 \text { X1it }+\beta 2 \text { X2it }+\beta 3 \text { X3it }+ \text { Eit } \\
\text { ROAit }=\beta 0 \text { it }+\beta 1 \text { BSit }+\beta 2 \text { CRit }+\beta 4 \text { MEit }+ \text { Eit }
\end{gathered}
$$

Where:

ROAit $=$ Represents return on asset of banks $i$ at time $t$ $\beta 0=$ Constant, $\mathrm{Y}$ intercept

Eit $=$ Error term

\section{Data Analysis}

Table 1. Descriptive Statistics.

\begin{tabular}{llllll}
\hline Variable & Obs. & Mean & Std. Dev. & Min & Max \\
\hline ROA & 48 & 0.0247083 & 0.0039731 & 0.018 & 0.034 \\
BS & 48 & 23.25021 & 0.8145603 & 21.39 & 24.74 \\
CR & 48 & 0.1372917 & 0.0212122 & 0.1 & 0.18 \\
ME & 48 & 110449.7 & 30875.75 & 42735.16 & 189370.1 \\
\hline
\end{tabular}

Source: Researcher's own computation (2020)

As per the result of descriptive statistics indicated in table 1, selected commercial banks have an average ROA of $2.47 \%$ with a standard deviation of 0.0039731 . Bank size which is measured in terms of natural logarithm of total asset of selected commercial banks has a mean of 23.25021 with a standard deviation of 0.8145603 . Mean of capital ratio is 0.1372917 which indicates equity of selected commercial banks is on average $13.729 \%$ of total asset with standard deviation of 0.0212122 . Management efficiency has mean of 110449.7 with the standard deviation of 30875.75 . It has largest mean and standard deviation when compared with other selected variables for this study.

Table 2. Interpretations of Strength of Correlation Coefficient.

\begin{tabular}{ll}
\hline Value of Coefficient & Relation between variables \\
\hline $0.00-0.19$ & Very weak \\
$0.20-0.39$ & Weak \\
$0.40-0.59$ & Moderate \\
$0.60-0.79$ & Strong \\
$0.80-1.00$ & Very strong \\
\hline
\end{tabular}

Source: Evans, 1996

Table 3. Correlation Analysis.

\begin{tabular}{lllll}
\hline ROA & BS & CR & ME & \\
\hline ROA & 1.0000 & & & \\
BS & -0.0850 & 1.0000 & & \\
CR & 0.1419 & -0.7046 & 1.0000 & 1.0000 \\
ME & 0.4203 & 0.7345 & -0.5213 & \\
\hline
\end{tabular}

Source: Researcher's own computation (2020)

According to the result revealed in the table 3 , negative correlation $(\mathrm{r}=-0.0850)$ is identified between banks size and ROA. Based on the correlation coefficient, it is very weak correlation. Capital ratio has a positive and very weak correlation $(\mathrm{r}=0.1419)$ with ROA but has a negative and strong correlation $(r=-0.7046)$ with bank size. Management efficiency has a positive and moderate correlation $(r=0.4203)$ with ROA, positive and strong correlation $(\mathrm{r}=0.7345)$ with bank size but negative and moderate correlation $(\mathrm{r}=-0.5213)$ with capital ratio.

Table 4. Test of Multicollinearity.

\begin{tabular}{lll}
\hline Variable & VIF & 1/VIF \\
\hline BS & 3.14 & 0.318465 \\
ME & 2.17 & 0.460507 \\
CR & 1.99 & 0.503555 \\
Mean VIF & 2.43 & \\
\hline
\end{tabular}

Source: Researcher's own computation (2020)

VIF test is performed to measure multicollinearity problem among independent variables of the study. As per the result of Table 4 VIF for each independent variable is less than 10 (cut off VIF) and the mean of VIF is also 2.43. Therefore, based on the result of VIF test the model of this study is free from the multicollinearity problem.

Regression Analysis

In this section, the researcher employed panel data analysis to examine the effect of bank specific factors on profitability of sampled commercial banks in Ethiopia. In order to identify the best model, either random effect or fixed effect model, hausman test was done. Based on the result of hausman test, random effect model is the best model fitted with the panel data used in this study to examine the effect of bank specific factors on profitability. Table 5 presents the result of panel data multiple regression analysis using random effect model. 
Table 5. Regression result of random effect model.

\begin{tabular}{|c|c|c|c|c|c|c|}
\hline \multicolumn{4}{|c|}{ Random-effect GLS regression } & \multicolumn{3}{|c|}{ Number of obs $=48$} \\
\hline \multicolumn{4}{|c|}{ Group variable: id } & \multicolumn{3}{|c|}{ Number of groups $=8$} \\
\hline \multicolumn{4}{|c|}{ R-sq: within= 0.5965} & \multicolumn{3}{|c|}{ Obs per group: $\min =6$} \\
\hline \multicolumn{4}{|c|}{ between $=0.3546$} & \multicolumn{3}{|c|}{ aver $=6.0$} \\
\hline \multicolumn{4}{|c|}{ overall $=\mathbf{0 . 5 2 6 5}$} & \multicolumn{3}{|c|}{$\max =6$} \\
\hline \multicolumn{7}{|c|}{ Wald chi2 $(3)=53.45$} \\
\hline \multirow{2}{*}{\multicolumn{7}{|c|}{$\begin{array}{l}\operatorname{corr}\left(\mathbf{u} \_\mathrm{i}, \mathbf{x}\right)=0 \text { (assumed) } \\
\text { (Std Err. adjusted for } 8 \text { clusters in id) }\end{array}$}} \\
\hline & & & & & & \\
\hline ROA & Coef. & \multirow{2}{*}{$\begin{array}{l}\text { Robust Std. Err. } \\
.0016629\end{array}$} & \multirow{2}{*}{$\frac{\mathbf{z}}{-2.99}$} & \multirow{2}{*}{$\frac{\mathbf{P}>|\mathbf{z}|}{0.003}$} & \multicolumn{2}{|c|}{ (95\% Conf. Interval) } \\
\hline$\overline{B S}$ & -.0034797 & & & & -.005759 & -.0012003 \\
\hline $\mathrm{CR}$ & .0429998 & .0344113 & 1.25 & 0.211 & -.0244451 & .1104446 \\
\hline ME & $1.38 \mathrm{e}-07$ & $2.65 \mathrm{e}-08$ & 5.20 & 0.000 & $8.59 \mathrm{e}-08$ & $1.90 \mathrm{e}-07$ \\
\hline cons & .0844957 & .0302612 & 2.79 & 0.005 & .0251848 & .1438066 \\
\hline sigma_u & .00212972 & & & & & \\
\hline sigma_e & .00241539 & & & & & \\
\hline rho & .4373945 & (fractions of varia & ue to u i) & & & \\
\hline
\end{tabular}

Source: Researcher's own computation (2020)

Based on the result of random effect model presented in the above table, table 5, the overall R-square statistics value of 0.5265 which shows the independent variables included in the model jointly explains for about $52.65 \%$ of variation in profitability. From the result indicated in the above table, there is a negative significant effect of bank size $(\beta=$ 0.0034797 and $\mathrm{P}<0.05)$ on profitability. Capital ratio has positive but insignificant $(\beta=0.0429998$ and $\mathrm{P}>0.05$ ) impact on profitability. Management efficiency has a positive and significant $\left(\beta=1.38 \mathrm{e} \_07\right.$ and $\left.\mathrm{P}<0.05\right)$ effect on profitability. $\mathrm{H}_{1}$ and $\mathrm{H}_{3}$ are supported with the result of the study that bank size significantly negatively influences profitability whereas management efficiency significantly positively influences profitability. But, $\mathrm{H}_{2}$ is not supported with the result of the study that capital ratio insignificantly positively affect profitability.

\section{Conclusions and Recommendations}

This paper attempted to examine the effect of some selected bank specific factors on profitability of commercial banks in Ethiopia including bank size, capital ratio and management efficiency. Based on the result of correlation result capital ratio and management efficiency have positive relationship with profitability but bank size has a negative relationship with profitability. All the independent variables included in the model have a VIF of less than 10, which indicates there is no multicollinearity problem.

Based on the regression result, bank size has a negative significant result on profitability. This indicates that when the size of banks increases profitability will decrease. Capital ratio has insignificant positive impact on profitability which implies that when capital of the bank increases profitability will increase but it is not a significant increase. Management efficiency has a significant positive effect on profitability. This implies that when banks improve their management efficiency profitability of banks will increase significantly. Based on what was discussed above it can be concluded that management efficiency is the major factor $\left(\beta=1.38 \mathrm{e} \_07\right)$ influencing the profitability of banks. Therefore, it is recommended for banks to focus on their management efficiency to improve their profitability.

\section{References}

[1] Gicharu, E., Zablon, E. and Ariemb, J. (2016). The Effect of Bank Specific Factors on Financial Performance of Commercial Banks in Kenya. International Journal of Sciences: Basic and Applied Research (IJSBAR), 30 (5), 165180, ISSN: 2307-4531.

[2] Mahmud, K., AvijitMallik, A., Imtiaz, F. and Tabassum, N. (2016). The Bank-Specific Factors Affecting the Profitability of Commercial Banks in Bangladesh: A Panel Data Analysis. International Journal of Managerial Studies and Research (IJMSR), 4 (7), PP 67-74, ISSN 2349-0330.

[3] Kawshala, H. and Panditharathna, K. (2017). The Factors Effecting on Bank Profitability. International Journal of Scientific and Research Publications, 7 (2), ISSN 2250-3153.

[4] Serwadda, I. (2018). Determinants of commercial banks' profitability: Evidence from Hungary. 66 (134).

[5] Mohammed, A. (2018). Determinants of the Financial Performance of Private Commercial Banks in Ethiopia: Bank Specific Factors Analysis. Global Journal of Management and Business Research: C Finance, 18 (3), ISSN: 2249-4588.

[6] Rahaman, M. and Akhter, S. (2015). Bank-Specific Factors Influencing Profitability of Islamic Banks in Bangladesh. Journal of Business and Technology, $\mathrm{x}(01)$.

[7] Suganya, J. and Kengatharan, L. (2018). Impact of bank internal factors on profitability of commercial banks in Srilanka: a panel data analysis. Journal of Business Studies, 5 (1).

[8] Nguyen, T., Luong, T. and Thuy, T. (2018). Analysis of internal factors affecting bank profitability: Evidence from listed banks on Vietnam stock market. The 5th IBSM International Conference on Business, Management and Accounting, Hanoi University of Industry, Vietnam.

[9] Maqbool, Q. and Kouser, R. (2015). Impact of bank specific and macroeconomic factors on bank profitability: a study on banking sector of Pakistan. Journal of Accounting and Finance in Emerging Economies, 1 (2). 
[10] Haliti, L., Ahmeti, S. and Rudhani, T. (2016). The impact of internal factors on bank profitability in Kosovo.

[11] Hirindu, K. and Kushani, P. (2017). The factors effecting on bank profitability of Sri Lankan domestic commercial banks. International Journal of Scientific and Research Publications.

[12] Sabri, M. (2016). Internal determinants of bank profitability: evidence from Turkish banking sector. International Journal of Economic Perspectives, 2016, 10 (1), 37-49.

[13] Ongore, V. O., \& Kusa, G. B. (2013). Determinants of financial performance of commercial banks in Kenya. International Journal of Economics and Financial Issues.
[14] Bhatia, A., Mahajan, P. and Chander, S. (2012). Determinants of profitability of private sector banks in India. Indian Journal of Accounting, 42 (2), 39-51.

[15] Sufian, F., \&Habibullah, M. S. (2009). Bank Specific and Macroeconomic Determinants of Bank Profitability: Empirical Evidence from the China Banking Sector. Front. Econ. China, 4 (2), 274-291.

[16] Macit, F. (2011). Bank Specific and Macroeconomic Determinants of Profitability: Evidence from Participation Banks in Turkey. Economics Bulletin, 32 (1). 